\title{
Urinary Complication Following Cystocele Repair in Pelvic Organ Prolapse
}

\author{
Shrestha $\mathbf{S}^{1}$ \\ ${ }^{1}$ Department of Obstetric and Gyanecology, Paropakar Maternity and Women's Hospital, Kathmandu
}

Received: January 20,2016 ; Accepted: February 20, 2016

\begin{abstract}
Aims: Pelvic organ prolapse is a common condition in our country which affects the quality of life of many women. After vaginal operations for genital prolapse, there is increased chance of urinary tract infections, retention of urine and re-catheterization. The objective of this study is to evaluate women with cystocele in terms of clinical profile, different modalities of treatment and the complication following repair.
\end{abstract}

Methods: It is a descriptive study carried out amongst 80 cases of cystocele irrespective of associated uterine descent and stress incontinence of urine in College of Medical Sciences - Teaching Hospital, Nepal from 1/9/2011 to 30/10/2013.

Results: During the study, 80 women with cystocele were enrolled. Majority of the women $(66.3 \%, \mathrm{n}=53)$ with cystocele were within 15 to 45 years and $53.8 \%(n=43)$ of them had parity beyond 5 . Among these women, $51.4 \%(n=41)$ had second degree cystocele and $23.8 \%(n=19)$ had stress urinary incontinence. Majority of the women $(58.8 \%, n=40)$ underwent vaginal hysterectomy with pelvic floor repair. Following surgery, the most common complication was urinary tract infection $(14.7 \%$, $\mathrm{n}=10$ ).

Conclusions: In this study, majority of the cases with cystocele were in the reproductive age with parity beyond 5 while maximum number of the women with cystocele had associated third degree uterocervical descent. Urinary tract infection was the commonest complication following surgical treatment followed by retention of urine.

Keywords: cystocele, pelvic organ prolapse, stress urinary incontinence, urinary tract infection.

\section{INTRODUCTION}

Pelvic Organ Prolapse (POP) is a significant public health problem in Nepal. ${ }^{1}$ It is characterized by downward displacement of structures that are normally located at the level of or adjacent to the vaginal vault. POP has a lifetime prevalence risk of $30-50 \%$ and its incidence increases with age. ${ }^{2-4}$ In Nepal, the prevalence of POP is quoted to be as high as $18-25 \% .{ }^{5}$ Various studies show that more than 6,00,000 women in Nepal suffer from POP and $2,00,000$ women require pelvic surgery for genital prolapse. ${ }^{6}$

Cystocele is a descent of the upper two-thirds of the anterior vaginal wall. Most common cause for cystocele is the transverse apical defect in the pubocervical septum which forms the floor of the urinary bladder. ${ }^{7}$ In about one third of the cases of cystocele there is an associated stress urinary incontinence (SUI) due to the weakness of pelvic

\section{CORRESPONDENCE}

Dr. Sweety Shrestha

Department of Obstetrics and Gynecology,

Paropakar Maternity and Women's Hospital, Kathmandu

Email: sweetyshree@hotmail.com

Phone: +977-9849440655 floor muscles and pubourethral ligament. Damage to these structures during childbirth results in the descent of the proximal urethra causing SUI.

After vaginal operations for cystocele there is increased chance of retention of urine due to the post-operative tissue swelling, pain, bladder atony, hematoma and vaginal pack. Postoperative urinary retention is associated with risk of over distention and disruption of supports and even permanent dextrusor muscle damage. ${ }^{1}$ The risk of urinary tract infection (UTI) increases with duration of urinary catheter. ${ }^{3}$ The available information demonstrates a three to $10 \%$ increased risk of bacteriuria per day of catheterization. $^{3-4}$

\section{METHODS}

It is a descriptive study conducted in the Department of Obstetrics and Gynecology in College of Medical Sciences - Teaching Hospital (COMS-TH), Nepal. Approval was taken from the ethical clearance committee of the hospital. A total of 80 cases of cystocele were included in the study during the period of two years $1 / 9 / 2011-30 / 10 / 2013$. All women with cystocele irrespective of associated uterine descent and urinary incontinence were included in the 
study after the informed written consent. Women with chronic respiratory illnesses and women who had previously undergone pelvic floor repair were excluded. Data were entered in Microsoft Office Excel Worksheet and statistical analysis was done using SPSS version 20.0. "p value" of less than 0.05 was considered significant.

\section{RESULTS}

In this study, $66.3 \%(\mathrm{n}=53)$ of the women were in the reproductive age group and $53.8 \%(\mathrm{n}=43)$ of them had parity beyond 5. Majority of these women $(51.4 \%, \mathrm{n}=35)$ had second degree cystocele (Table 1) and $42.5 \%(\mathrm{n}=34)$ had associated third degree cervical descent (Table 2).

Table 1: Distribution of severity of cystocele in operative cases $(\mathrm{n}=68)$

\begin{tabular}{|ccc|}
\hline Cystocele & Frequency & Percent \\
\hline I degree & 11 & 16.2 \\
II degree & 35 & 51.4 \\
III degree & 22 & 32.4 \\
Total & 68 & 100 \\
\hline
\end{tabular}

Table 2: Association of uterine descent among study cases $(\mathrm{n}=\mathbf{8 0})$

\begin{tabular}{|lllll|}
\hline \multicolumn{2}{l}{ Cervical descent } & \multicolumn{3}{l|}{ Cystocele } \\
Degree & Frequency & Percent & Frequency & Percent \\
\hline I & 12 & 15 & $12^{*}$ & 15 \\
II & 16 & 20 & 16 & 20 \\
III & 34 & 42.5 & 34 & 42.5 \\
Procidentia & 18 & 22.5 & 18 & 22.5 \\
Total & 80 & 100 & 80 & 100 \\
\hline
\end{tabular}

*Traction cystocele concomitant to uterine descent did not require surgical intervention.

Urinary incontinence was seen in $48.8 \% \quad(n=39)$ of cases. Out of these, SUI was observed in $23.8 \%$ $(\mathrm{n}=19)$ cases, overactive bladder in $15 \%(\mathrm{n}=12)$, while mixed incontinence was observed in only $10 \%$ $(n=8)$ of cases (Table 3$)$.

Table 3: Urinary incontinence associated with cystocele $(\mathrm{n}=80)$

\begin{tabular}{|lll|}
\hline Nature of incontinence & Frequency & Percent \\
\hline SUI & 19 & 23.8 \\
Urge incontinence & 12 & 15 \\
Mixed & 8 & 10 \\
Total & 28 & 48.8 \\
\hline
\end{tabular}

Vaginal hysterectomy with pelvic floor repair $(\mathrm{VH}$ with PFR) was the most common $(58.8 \%, \mathrm{n}=40)$ surgical operation followed by VH with PFR with placation of bladder neck $(22.2 \%, \mathrm{n}=15)$ (Table
4). Most common $(14.7 \%, \mathrm{n}=10)$ post operative complication was UTI followed by fever $(8.8 \%, \mathrm{n}=6)$ and re-catheterization of urine $(8.8 \%, \mathrm{n}=6)($ Table 5$)$.

Table 4 : Analysis of surgical procedure undertaken $(\mathrm{n}=68)$

\begin{tabular}{|lll|}
\hline Procedure undertaken & Frequency & Percent \\
\hline $\begin{array}{l}\text { Manchester repair with } \\
\text { Anterior Colporraphy }\end{array}$ & 9 & 13.2 \\
$\begin{array}{l}\text { Manchester repair with } \\
\text { plication of bladder neck }\end{array}$ & 4 & 5.8 \\
$\begin{array}{l}\text { Vaginal Hysterectomy with } \\
\text { Surgical Pelvic floor repair }\end{array}$ & 40 & 58.8 \\
$\begin{array}{l}\text { Vaginal Hysterectomy with } \\
\text { Pelvic floor repair with } \\
\text { plication } \\
\text { of bladder neck }\end{array}$ & 15 & 22.2 \\
Total & 68 & 100 \\
\hline
\end{tabular}

Table 5: Analysis of post operative complications $(\mathrm{n}=68)$

\begin{tabular}{|lll|}
\hline Post operative complications & ${ }^{*}$ Frequency & Percent \\
\hline Fever & 6 & 8.8 \\
Wound sepsis & 1 & 1.4 \\
Secondary hemorrhage & 1 & 1.4 \\
Inability to pass urine & 2 & 2.8 \\
Urinary tract infection & 10 & 14.7 \\
Incomplete voiding & 5 & 7.3 \\
Need for re catheterization & 6 & 8.8 \\
Total & 31 & 45.2 \\
\hline
\end{tabular}

*Some patients had more than one symptom.

Table 6: Analysis of post-voidal residual volume $(\mathrm{n}=68)$

\begin{tabular}{|lll|}
\hline Postvoidal residue volume & Frequency & Percent \\
\hline$<50 \mathrm{ml}$ & 42 & 61.8 \\
$50-100 \mathrm{ml}$ & 8 & 11.8 \\
$100-200 \mathrm{ml}$ & 12 & 17.6 \\
$200-500 \mathrm{ml}$ & 6 & 8.8 \\
Total & 68 & 100 \\
\hline
\end{tabular}

\section{DISCUSSION}

More than one million of Nepali women suffer from uterine prolapse and the majority of these patients are of reproductive age group. ${ }^{1}$ In a study of 1,49,544 women a life time risk of $11.1 \%$ was seen for surgery for POP and urinary incontinence. ${ }^{9}$ However treatment option for cystocele ranges from nonsurgical treatment for mild cystocele to surgical correction for moderate and severe cystocele. The postoperative period following cystocele repair always remained a matter of concern for the surgeon. This is due to post operative tissue swelling, pain, transient bladder atony, or haematoma with retention of urine. ${ }^{10}$ Therefore postoperative indwelling catheterization 
for certain days after prolapse surgery has become an accepted practice. On the other hand the insertion of indwelling catheter also increases the risk of urinary tract infection and the infection rate increases with the length of time a catheter remains in situ. ${ }^{8}$

Sah et al. observed maximum number $(n=632)$ of cases among 40-70 years women which is similar to study done by Begum et al. where maximum cases i.e. $69.44 \%(n=72)$ was seen among $41-60$ years. ${ }^{11,12}$ Similar observation was done by Sultana et al. where the maximum number of cases was seen in women of 51 years and above. ${ }^{13}$ In this study, majority of the women with POP were in reproductive age group which may be explained by the early age of marriage, short spacing, and early postpartum work resumption. In the study, there was total of $43(53.8 \%)$ cases of parity beyond 5 which is similar to the study done by Begum et al. where $54.16 \%(n=72)$ of cases had parity of 5-9. ${ }^{12}$ In study done by Menur et al. 73.6\% $(n=129)$ of women had parity beyond 5. ${ }^{14}$

POP can be either descent of anterior vaginal wall with its contents, posterior vaginal wall with its contents and uterine prolapse or its various combinations. Similar to the study, in a study done by Sclterf et. al. cystocele was the commonest $(57 \%, \mathrm{n}=286$ ) followed by urethrocele $(28 \%, \mathrm{n}=138) .{ }^{15}$ Akmel and Segni similarly reported cystocele being the most common in their cases with uterine prolapse $(38.1 \%$, $\mathrm{n}=8$ ) as opposed with both anterior and posterior vaginal wall descent $(14.3 \%, \mathrm{n}=3) .{ }^{14}$

In this study, second degree cystocele was the commonest $(51.4 \%, \mathrm{n}=35)$ followed by third degree cystocele $(32.4 \%, n=22)$. Further there was association between the severities of the degree of the descent of the cervix with that of severity of grade of cystocele. Sclherf et al. analyzed various grades of cystocele amongst 286 cases out of a total of 488 uterovaginal prolapse and found symptomatic association of cystocele in only $11 \%(n=37)$ of cases in mild, $18 \%(\mathrm{n}=23)$ of cases in moderate and $50 \%$ $(n=6)$ cases of severe cystocele. ${ }^{15}$ Similarly Bandiera et al. found $29 \%(\mathrm{n}=74)$ grade II cystocele, $47.3 \%$ ( $\mathrm{n}=74)$ grade III cystocele and $23 \%(\mathrm{n}=74)$ grade IV cystocele. ${ }^{16}$ Likewise Dietz et al. reported various degree of cystocele out of that 971 cases of POP, grade 0 cystocele in $27 \%(n=971)$, grade 1 in $32 \%$ $(n=971)$, grade I1 in $23 \%(n=971)$ and grade III in $16 \%(n=971)$ of cases respectively. ${ }^{17}$
Urinary incontinence, especially the SUI is a well recognized manifestation in cases with cystocele. Luka et al. observed SUI in $15 \%(n=4458)$ of women and overactive bladder in $13 \%(n=4458)$ of their cases while Khan et al. observed a similar incidence of SUI $(14.78 \%, \mathrm{n}=69) .{ }^{18,19}$ To the contrary, Bai et al. observed SUI in $63.3 \%(n=19) .{ }^{20}$ Further search in the literature revealed that Zargham et al. reported on 100 cases of POP, an incidence of $53 \%(n=53)$ of SUI, $9 \%(n=9)$ of overactive bladder and $38 \%(n=38)$ of cases at mixed incontinence. ${ }^{21}$

The nature of intervention was decided by the extent of the cystocele, presence of SUI, degree of genital prolapse and the desire of further child bearing. In this study, 68 cases of cystocele ( $85 \%$ ) underwent various forms of surgical corrections and traction cystocele concomitted with first degree genital prolapse did not require surgical correction and was advised to do Kegel's exercise but in the study done by Tahmin and Begum, and Begum et al. all the cases underwent surgical correction. ${ }^{10,12}$

Kokabi et al. divided their cases of anterior colporraphy along with repair of SUI into 3 different groups for indwelling bladder drainage into 1, 2 and 4 days. ${ }^{22}$ As opposed to these Thakur et al. divided their cases of VH with PFR into 2 groups of short term catheterization (24hrs) and long term catheterization (72 hrs). ${ }^{23}$ In this study, the duration of postoperative indwelling catheter were divided into different period depending on the nature of surgical intervention. The maximum duration of indwelling catheter was beyond 96 hours seen in $8.8 \%(n=6)$ of the cases due to post surgical bladder atony and incomplete voiding even after initial period of indwelling catheter. Otherwise indwelling catheter was kept between 24-48 hours following Manchester with anterior colporraphy, between 48 - 72 hours following VH with PFR and 72 - 96 hours following VH with PFR with Kelly's plication of bladder neck .

Similar to this study, in the study done by Begum et al. ${ }^{12}$ UTI was the commonest complication $(20.83 \%$, $n=15)$ followed by urinary retention $(4.16 \%, n=3)$. In contrast to this, Sah et al found retention of urine in $1.74 \%(n=11)$ cases and UTI in $0.79 \%(n=5)$ cases. ${ }^{11}$

While on one hand practice of placement of indwelling catheter has become a routine following surgery for cystocele prolapse to overcome retention of urine due to postoperative tissue edema and transient bladder atony, on the other hand indwelling catheter also 
increases the risk of UTI. Therefore the best way to prevent catheter related problem is removal of catheter as soon as possible. Although there are no consensuses regarding the removal of catheter, certain authors have found earlier removal after 24 hours is beneficial. The best assessment of bladder function after removal of catheter is postvoidal residual urine.

\section{CONCLUSIONS}

In this study, majority of the cases with cystocele were in the reproductive age with parity beyond five while maximum number of the women with cystocele had associated third degree uterocervical descent. Urinary tract infection was the commonest complication following surgical treatment followed by retention of urine.

\section{REFERENCES}

1. Bodner-Adler B, Shrivastava C, Bodner K. Risk factors for uterine prolapse in Nepal. Int Urogynecol J Pelvic Floor Dysfunct. 2007;18: 1343-6.

2. Cutner AS, Elneil S. The vaginal vault. BJOG. 2004;1 1 1(Suppl 1): 79-83.

3. Samuelsson EC, Victor FT, Tibblin G, Svardsudd KF. Signs of genital prolapse in a Swedish population of women 20 to 59 years of age and possible related factors. Am J Obstet Gynecol. 1999;180(2 Pt 1): 299-305.

4. MacLennan AH, Taylor AW, Wilson DH, Wilson D. The prevalence of pelvic floor disorders and their relationship to gender, age, parity and mode of delivery. BJOG. 2000;107: 1460-70.

5. Tuladhar H. An overview of reproductive health of women in Bajhang district. Nepal Med Coll J. 2005;7: 107-1 1.

6. Subedi M. Uterine prolapse, mobile camp approach and body politics in Nepal. Dhaulagiri J Soc Anthropol. 2010;4: 21-40.

7. Zimmerman CW, editor. Telinde's Gynaecology. 10th ed. New Delhi: Wolters Kluwer Lippincott Williams \&Wilkins; 2009.

8. Pant PR. An effective short duration postoperative catheterization after vaginal hysterectomy and pelvic floor repair. JIOM. 2006;28: 33-5.

9. Olsen AL, Smith VJ, Bergstrom JO, Colling JC, Clark AL. Epidemiology of surgically managed pelvic organ prolapse and urinary incontinence. Obstet Gynecol. 1997;89: 501-6.

10. Tahmin K, Begum SN. Short term verus conventional catheterization after genital prolapse surgery. Bangladesh $\mathrm{J}$ Obstet Gynaecol. 2011;26: 68-71.

11. Sah DK, Doshi NR, Das CR. Vaginal hysterectomy for pelvic organ prolapse in Nepal. Kathmandu Univ Med J. 2010;8: 2814.

12. Begum S, Sharmin S, Sultana P, Chowdhury AN, Sultana P, Nabi S, et al. Clinical profile and management of uterovaginal prolapse with lower urinary tract symptom (LUTS). Bangladesh J Urol. 2011;14: 26-30.
13. Sultana N. Clinical profile and management of 100 cases of uterovaginal prolapsed in Holy Family Red Crescent Medical College Hospital, Dhaka (Dissertation). Bangladesh College of Physicians \& Surgeons. 2008:64.

14. Akmel M, Segni H. Pelvic organ prolapse in Jimma University specialized hospital, Southwest Ethiopia. Ethiop J Health Sci. 2012;22:85-92.

15. Scherf C, Morison L, Fiander A, Ekpo G, Walraven G. Epidemiology of pelvic organ prolapse in rural Gambia, West Africa. BJOG. 2002;109: 431-6.

16. Bandiera S, Raciti G, Aloisi A, Arena M, Giordano R, Giunta $\mathrm{G}$, et al. Double transobturator approach to treating cystocele. Urogynaecologia Int J. 2008;22: 17-24.

17. Dietz HP. Prolapse worsens with age, doesn't it? Aust N Z J Obstet Gynaecol. 2008;48: 587-91.

18. Lukacz ES, Lawrence JM, Contreras R, Nager CW, Luber KM. Parity, mode of delivery, and pelvic floor disorders. Obstet Gynecol. 2006;107: 1253-60.

19. Khan K. Surgical management of genital prolapse and its immediate morbidity, (Dissertation), Dhaka. Bangladesh College of Physicians \& Surgeons. 2005:54.

20. Zargham M, Alizadeh F, Moayednia A, Haghdani S, NouriMahdavi K. The role of pelvic organs prolapse in the etiology of urinary incontinence in women. Adv Biomed Res. 2013;2: 22

21. Bai SW, Jeon MJ, Kim JY, Chung KA, Kim SK, Park KH Relationship between stress urinary incontinence and pelvic organ prolapse. Int Urogynecol J Pelvic Floor Dysfunct. 2002;13: 256-60.

22. Kokabi R, Fereidouni Z, Meshkibaf MH, Miladpoor B. Post operative voiding efficacy after anterior colporrhaphy. Acta Med Iran. 2010;48: 33-5.

23. Thakur N, Gurung G, Rana A. A Randonized controlled trial comparing short-term versus long-term catheterization after vaignal prolapse surgery. Nepal J Obstet Gynaecol. 2007;2: 29-34. 